\title{
Embryology teaching - improving the learning experience
}

This article was published in the following Dove Press journal:

Advances in Medical Education and Practice

\section{Nikhil V Math \\ Michael Y Mahgerefteh}

Faculty of Medicine, Imperial College London, South Kensington Campus, London, UK
Correspondence: Nikhil V Math Faculty of Medicine, Imperial College London, Level 2, Faculty Building, South Kensington Campus, London SW7 2AZ, UK

Tel +447847346060

Emailnvm13@ic.ac.uk

\section{Dear editor}

We read with great interest the article by Kazzazi and Bartlett ${ }^{1}$ regarding embryology teaching methods. While we commend their efforts regarding the condensing of teaching for medical students, we have highlighted the aspects which may be worth considering.

The delivery of lectures including case studies is welcomed. Research has shown that not only student satisfaction but also knowledge gained is superior using an integrated teaching approach. ${ }^{2}$ While a wholly integrated approach also involves exposure to patients and problem-based learning, ${ }^{3}$ starting by integrating information in the classroom is a cornerstone to success.

We were impressed by the study where teaching was kept "engaging and insightful" through the use of "illustrations" to target "visual learners". Building on this, one teaching aspect which could have contributed to this goal is the use of tactile learning tools in conceptual demonstration. With embryology often demanding intensely three-dimensional thinking, the construction of models by students of embryology has been shown to contribute to significantly improved learning outcomes compared to those without. ${ }^{4}$ Indeed, at Imperial College London, the teaching of the embryological development of the cardiovascular system is aided by medical students constructing models of the early tubal heart using malleable putty in lectures.

Summary lectures as an adjunct to traditional curriculum lectures are not uncommon in undergraduate teaching, and it certainly appears that these students felt more confident in their understanding and appreciation of embryology following this course. At Imperial, in order to gauge understanding, informal testing of the taught subject is conducted via the audience response system (ARS) "Mentimeter". This removes the subjectivity of the feedback seen in this study, allowing the teacher to better know if their topic has been grasped. Such ARS systems have been shown to be useful both as a tool to measure teaching effectiveness as well as improving long-term retention of facts by students. ${ }^{5}$

Additionally, the students were asked about an improvement in knowledge and understanding directly after the course. While the paper highlighted the deficiencies in the formal embryology lectures already received, surely at the end of almost any teaching, regardless of quality, the students would also have some degree of improved 
knowledge compared to the start. Perhaps, there would be merit in comparing these results with a cohort receiving traditional lectures in order to assess whether there is a significant difference between these groups. It would also be interesting if the reported outcomes were re-assessed at a later date, even by 1 week, thereby representing a more pertinent outcome with regard to the understanding and retention of knowledge for examination purposes.

\section{Disclosure}

The authors report no conflicts of interest in this communication.

\section{References}

1. Kazzazi F, Bartlett J. Condensing embryology teaching for medical students: can it be taught in 2 hours? Adv Med Educ Pract. 2017;8:797-806.

2. Khaki A, Tubbs R, Zarrintan S, et al. The first year medical students' perception of and satisfaction from problem-based learning compared to traditional teaching in gross anatomy: introducing problem-based anatomy into a traditional curriculum in Iran. Int J Health Sci. 2007; 1(1):113-118.

3. Brauer $\mathrm{D}$, Ferguson $\mathrm{K}$. The integrated curriculum in medical education: AMEE Guide No. 96. Med Teach. 2014;37(4):312-322.

4. Aversi-Ferreira T, Aversi-Ferreira R, Nascimento G, et al. Teaching embryology using models construction in practical classes. Int J Morphol. 2012;30(1):188-195.

5. Siddiqui F, Iqbal I, Azizi S. Using mobile audience response systems to enhance medical education: a medical student perspective. $A d v$ Med Educ Pract. 2017;8:325-327. 


\section{Authors' reply}

Fawz Kazzazi

Jonathan Bartlett

School of Clinical Medicine, University of Cambridge,

Cambridge, UK

Correspondence: Fawz Kazzazi

School of Clinical Medicine, University of Cambridge, 37 Grange Road,

Leckhampton House, Cambridge CB2 IRH, UK

Tel +4477542 2005

Email fk276@cam.ac.uk

\section{Dear editor}

We are delighted to see that we have engaged the medical community to think about embryology teaching within medical schools, such as in Math and Mahgerefteh's response letter.

We feel there may be some basic misunderstanding surrounding the course that we delivered, ${ }^{1}$ and we would like to respond to this letter to alleviate that. As the title suggested, the original course wholly covered the embryology curriculum that is deemed sufficient by most medical schools. It provided a simpler and more methodological way to teach embryology. Therefore, this was not a "summary" lecture, to the extent that some of the feedback received suggested there was at times additional information.

While we will consider the adoption of the Mentimeter, we do not believe at all that there was extraordinary subjectivity in the feedback received for our study. The questionnaires used are in line with what is adopted nationwide and were filled in anonymously by hundreds of students. The adoption of the Mentimeters would allow digitalization of this process and potential for real-time feedback.

Furthermore, we would like more information from readers about the adoption of tactile teaching in the setting of 100-200 students in a lecture theater. We can see the academic value of such teaching methods, ${ }^{2}$ but the practical application, scalability, and high capital make it an unreasonable request at this stage for us.

Unfortunately, we do not share the authors' belief that any teaching will improve students' knowledge. We implore them to consider their own experiences in such scenarios and the real-life practicality of getting feedback. If the teaching was of poor quality and tackled a difficult subject, then the feedback questionnaires would not have demonstrated very high marks across all sections. The proposed method to reassess the understanding at a later date is of no real worth. In the interim, students will have undergone various teaching sessions as well as experiences outside of their degree; the scores will inevitably not be reflective of the quality of the teaching session but the student's ability to retain masses of information despite other stimuli.

Furthermore, double-blind trial studies of teaching methodologies are always desirable. However, this will be extremely difficult to accomplish due to students exchanging information between lectures. Our sole focus is to improve student engagement with embryology; for some, this will be helping them learn it from attending the lectures and for others, the lecture will provide a solid reference material for their revision. It is difficult to assess these effects with linear approaches to assessment and uncontrolled environments.

\section{Disclosure}

The authors report no conflicts of interest in this communication.

\section{References}

1. Kazzazi F, Bartlett J. Condensing embryology teaching for medical students: can it be taught in 2 hours? Adv Med Educ Pract. 2017; 8:797-806.

2. Aversi-Ferreira T, Aversi-Ferreira R, Nascimento G, et al. Teaching embryology using models construction in practical classes. Int J Morphol. 2012;30(1):188-195.

Dove Medical Press encourages responsible, free and frank academic debate. The content of the Advances in Medical Education and Practice 'letters to the editor' section does not necessarily represent the views of Dove Medical Press, its officers, agents, employees, related entities or the Advances in Medical Education and Practice editors. While all reasonable steps have been taken to confirm the content of each letter, Dove Medical Press accepts no liability in respect of the content of any letter, nor is it responsible for the content and accuracy of any letter to the editor.

\section{Publish your work in this journal}

Advances in Medical Education and Practice is an international, peerreviewed, open access journal that aims to present and publish research on Medical Education covering medical, dental, nursing and allied health care professional education. The journal covers undergraduate education, postgraduate training and continuing medical education including emerging trends and innovative models linking education, research, and health care services. The manuscript management system is completely online and includes a very quick and fair peer-review system. Visit http://www.dovepress.com/testimonials.php to read real quotes from published authors. 